\title{
GIFFEN GOODS, BACKWARD BENDING SUPPLY CURVES, PRICE CONTROLS AND PRAXEOLOGY; OR, WHO'S AFRAID OF THE BIG BAD BOOGIE MAN OF GIFFEN GOODS AND BACKWARD BENDING SUPPLY CURVES? NOT US*
}

\author{
WALTER BLOCK** \\ WILLIAM BARNETT, II***
}

Resumen: ¿Cuál es el status del análisis sobre los efectos de las leyes de salario mínimo? ¿Empírico o praxeológico? Nosotros defendemos lo segundo. ¿Pueden analizarse mejor los efectos de dichas leyes suponiendo curvas de oferta y demanda anómalas (como las de los bienes Giffen)? Como en el análisis tradicional se produce una mala asignación de recursos. En todo caso, tanto tales curvas, como las tradicionales son muy problemáticas.

Palabras clave: Control de precios, praxeología, bienes de Giffen, positivismo lógico.

Clasificación JEL: DO.

Abstract: What is the status of claims about the effects of minimum wage laws? Empirical or praxeological? We claim the latter. How can the effect

* The idea for this present paper arose out of a presentation the first mentioned author made to the George Mason University Austrian Seminar on 2/16/04. This author thanks the entire membership of this Seminar, and especially Professors Peter Boettke and Bryan Caplan.

** Harold E. Wirth Eminent Scholar Endowed Chair and Professor of Economics College of Business Administration. Loyola University New Orleans 6363 St. Charles Avenue, Box 15, Miller 321. New Orleans, LA 70118. c.v.: http:/ / www.cba.loyno.edu/ faculty.html. Office: (504) 864-7934. dept: (504) 864-7944. fax: (504) 864-7970. wblock@loyno.edu. http:/ /www.WALTERBLOCK.COM.

*** Associate Professor of Economics. Loyola University New Orleans, 6363 St. Charles Ave. New Orleans, La. 70118. Office: (504) 864-7950. Wbarnett@loyno.edu 
of such legislation be best analyzed under the assumption of mis-behaving supply (backward bending) and demand (positively sloped, based on positing Giffen goods) curves? In the usual manner: resource misallocation still occurs. But this is only arguendo. More radically, such curves are themselves problematic. Even more radically, this, too, applies to «well behaved» supply and demand curves as well.

Key words: Backward Bending Supply Curves, Price Controls, Praxeology, Giffen Goods, Logical Positivism.

JEL Classification: DO.

\section{I \\ INTRODUCTION}

Card-Krueger (1994) attempted to undermine the claim that minimum wage laws lead to unemployment for unskilled workers. A spate of articles written in response to this finding charged that this research was mistaken.

But a funny thing happening on the way to this particular economic forum. The economic methodology of many of these critics ${ }^{1}$ is firmly embedded in the logical positivist philosophy: there is no such thing as absolute truth in economics; all claims in this field are merely hypothesis, which must be tested against empirical reality (Friedman, 1953). One would expect from this sort of background that practitioners would greet a data point such as that furnished by Card-Krueger (1994) with a certain amount of equanimity. After all, if induction is the be all and end all of economics, and economic theory is at best the tail, not the dog itself, then when an unusual empirical finding of this sort emerges, as it does every few years or so, then, perhaps, the attitude we could expect from logical positivists would be along the lines of: "Oh, well, that is interesting. Perhaps economic law operated differently in the last decade of the $20^{\text {th }}$ century than it has before or since.» Or, «Maybe supply and demand simply

1 See on this Mankiw (2001), Deere, Murphy, and Welch (1995), Neumark and Wascher (1995), Becker (1995). 
does not apply to New Jersey» (the area of study of Card-Krueger, 1994).

Instead, a very different sort of reply emanated from this quarter. Mankiw (2001) avers «We can't ignore law of supply and demand.» And in the view of Deere, Murphy, and Welch (1995, emphasis added): "Artificial increases in the price of unskilled laborers inevitably lead to their reduced employment.»

The obvious retort of the true blue logical positivist would be: «The law of supply and demand, forsooth?» There is no such thing as an invariable law in economics. Any supposed «law» is only as good as the most recent econometric regression equation. Why, then, should we doubt Card and Krueger, who are, supposedly, reputable economists? And what is with this «inevitable» business? Yes, the economic theory of supply and demand strongly suggests that placing a minimum wage above the equilibrium point will create unemployment, but the proof is in the empirical pudding, not in «blackboard» economics.

It is our contention, however, that these anti minimum wage law retorts are quite proper. If they are incompatible with the logical positivist vision, then so much the worse for the latter (Block, 1999, 2003). If there is a «tension» (e.g., logical contradiction) between the avowed but mistaken methodology of economists such as Friedman, Mankiw, Deere, Murphy, Welch, Neumark, Wascher, Becker, on the one hand, and on the other their correct supply and demand based analysis of minimum wages, then it is the former that must be jettisoned.

What, then, is the proper ontological status of the analysis of the critics of Card and Krueger? It is the contention of the present paper that it is praxeology (Block, 1973, 1986, 1999, 2003; Batemarco, 1985; Bohm-Bawerk 1994 [1890]; Bostaph, 1978; Buchanan, 1982; Cowan and Rizzo, 1996; Cubeddu, 1993; Gordon, 1993a, 1993b; Hoppe, 1989, 1990, 1995; Hulsmann, 2000; Huerta de Soto, 1998; Kirzner, 1976a, 1976b; Menger, 1960; Mises, 1976, 1978, 1985, 1990, 1998; Rizzo, 1979; Rothbard, 1951, 1957, 1976, 1993, 1997; Selgin, 1988; Smith, 1996), not empirical economics. Briefly, praxeology is the view that economics is not a branch of the empirical sciences, such as physics or chemistry, but rather can best be understood as a deductive discipline, along 
with such callings as mathematics, geometry and logic. Starting with such basic and undeniable upon pain of self-contradiction premises as man acts purposefully in order to render the future more to his liking that would otherwise obtain, the "tests» of this science are its solely the internal logic of its argumentation. Empirical evidence can illustrate apodictic necessary economic law, but cannot test it. If a regression equation appears to conflict with, say, the law of supply and demand that a price pegged above equilibrium will create surpluses (e.g., unemployment in the case of wage minima), then it is the former that must be rejected, not the latter. In the same way, if it appears that there is a triangle of other than 180 internal degrees, or a calculation which «demonstrates» that the Pythagorean theorem does not apply to right angled triangles, we ignore the former, not the latter.

In the present paper, we attempt to deal with one challenge to our thesis. The objection is that the standard model of perfect competition assumes downward sloping demand curves, and upward sloping supply curves. However, we cannot blithely assume this to be the case. To wit, there is always the possibility of Giffen Goods and Backward Bending Supply Curves. ${ }^{2}$

In section II we address the issue of mis-behaving supply and demand curves. Section III is devoted to an exploration of price controls in the context of upward sloping demand and downward sloping supply curves. Section IV maintains that misbehaving supply and demand curves are internally contradictory and in section $\mathrm{V}$ we make the case for the invalidity of supply and demand curves, whether misbehaving or not, from an Austrian perspective. We conclude in section VI.

2 Another challenge to our thesis stems from the so-called market failures of monopoly and monopsony. However, in this paper we abstract from the claim that monopoly and monopsony can render problematic the praxeological status of price control analysis. For a critique of neoclassical monopoly theory, see Anderson, et. al. (2001), Armentano (1972, 1982, 1991), Armstrong (1982), Block (1977, 1982, 1994), Boudreaux and DiLorenzo (1992), DiLorenzo (1997), DiLorenzo and High (1988), High (1984-1985), McChesney (1991), Rothbard (1970), Shugart (1987), Smith (1983). For an explicit critique of neoclassical monopsony theory see Block and Barnett (unpublished). 
II

\section{MISBEHAVING SUPPLY AND DEMAND CURVES}

It is a basic premise of all schools ${ }^{3}$ of economic thought that price controls cause shortages or surpluses, assuming minimum prices above equilibrium and maximum prices below that point. But is this finding merely an empirical claim which can upon occasion be rendered false, or is it a praxeological one, which must of necessity always prevail?

If we can but rely on the well behavedness of supply and demand curves, according to one line of reasoning, it cannot be denied that suitably placed price minima will engender surpluses and maxima, shortages. However, in this view, no such premises may be relied upon, given that Giffen goods foster upward sloping demand curves while backward bending supply curves (BBSCs) result in, as their name implies, supply curves which slope downward or fall forward. This, alone, would not present insuperable problems for the theory, provided, only, that only one of these curves "misbehave» at a time, and that these conditions still apply: $\mathrm{S}>\mathrm{D}$ above equilibrium and $\mathrm{D}>\mathrm{S}$ below.

For example, in both 1 and 2 these conditions obtain. Despite the "misbehavior» of one curve in each case, in these two diagrams the usual analysis applies. That is, $\mathrm{D}>\mathrm{S}$ implies a price rise, and $\mathrm{S}>\mathrm{D}$ a fall, both in the direction of where the two curves cross, or equilibrium. However, in 3 and 4 only one curve slopes the «wrong» way, and, we arrive at an unstable «equilibrium»: any deviation in price from the intersection of supply and demand will result in either an infinite or a zero price. ${ }^{4}$ In diagram 5 , both $\mathrm{S}$ and D slope in «improper» directions, to this same end.

So much for the simple cases; next, we consider the more complicated ones. Diagrams 6 and 7 illustrate cases featuring a BBSC and, respectively, cases where $\mathrm{D}$ «behaves» and then

${ }^{3}$ We include Austrianism and neo-classical economics under this rubric. We know little, and care less, about the views on price controls of the Marxists, not considering them as economists.

4 Similarly, any deviation in quantity from the intersection of S and D will result in either a zero or infinite amount of product being offered for sale. 
«misbehaves.» Take 6 first. Point A is an unstable one, while B is stable. The identical result obtains in 7. So, for our purposes, it does not matter which one is first reached in the market. More strictly speaking, A in both cases is stable. If ever the market were to stumble onto this point, there is no reason it could not continue to remain there, provided only that no other changes took place in either this market or in any other related ones. However, this is impossible, praxeologically, as human action (Mises, 1949) must always occur in an economy.

The point of the foregoing is that, according to the line of reasoning we are calling into question, when both $S$ and $D$ slope in their usual directions, or, no more than one of them are vertical and/or horizontal at the extreme, or, even in some cases, when one misbehaves but not the other (e.g., as depicted in 1 and 2), then, if we also abstract from the cases of monopoly and monopsony, it is apodictic that price controls create shortages and surpluses. However, when these assumptions cannot be made, then all bets are off in this regard. It still may be that price controls have these deleterious effects, but any such contention is no long as matter of praxeology; now, it is purely and entirely an empirical matter, and while, based on our experience these results are still highly likely, they are only just that: probable, but not necessary.

III

\section{PRICE CONTROLS WITH UPWARD SLOPING DEMAND} AND DOWNWARD SLOPING SUPPLY

Let us look at these contentions more carefully. Take diagram 5 as a case in point. If regulations set the price above (below) «equilibrium» there will still be forcibly opened a wedge between $S$ and D. Only now, instead of a surplus (shortage) there will be a shortage (surplus). The obverse occurs with a price set below «equilibrium.» But so what. It is still true, praxeologically, not merely empirically, that these (opposite) wedges will be opened up as a result of such laws. We must of course agree that, rather than there being a market tendency for price to approach 
«equilibrium» the very opposite will occur. But, again, so what? Price controls, even in the alternative universe, still misallocate resources, create havoc and dis-coordination in society, no matter the shape of the $S$ and D curves.

IV

\section{MISBEHAVING SUPPLY AND DEMAND CURVES ARE INTERNALLY CONTRADICTORY}

We now call into question the weird shapes of the $S$ and $D$ curves we have so far, arguendo, been positing to exist. If we do so, successfully, then the arguments against our claim that price controls create shortages and surpluses can further be established as an apodictic matter, not merely an inductive one.

It is easy enough to dispose of these misbehaving functions as an empirical matter. We do not, as a matter of fact, witness the wild swings in price (and/or quantity) that are implied by upward sloping demand, and/or downward sloping supply of the sort depicted in 5. Prices do not vary between zero and infinity, and then back again, in bewildering fashion. Therefore, such situations can be dismissed on inductive grounds. ${ }^{5}$

If there were all there were to the matter, however, we would have to concede to the very proposition against which we are arguing. These «misbehaving» curves seemingly 6 overturn our traditional case against price controls, and we can only disregard them as an empirical matter. Therefore, we cannot make our case against price minima and maxima on praxeological grounds. Happily, though, for our own side of this debate, we can do better: we can dispose of these mischievous and misbegotten curves not only on inductive grounds, but also as a matter of praxeology.

How so? Curves such as those illustrated in diagram 5 imply either infinite or zero prices. But entertaining either notion is to commit an internal self-contradiction. Thus, each may be dismissed

${ }^{5}$ Garrison (1985) maintains that the Giffen good entails a built-in violation of the ceteris paribus assumption.

${ }^{6}$ Apart from the considerations mentioned in section III, above. 
on logical grounds. An infinite price, on the one hand, is on its face, an utter impossibility. Under such a condition, all resources and human effort, literally, would be sunk into this one product, and there would be no room for anything else. To wit, no further human action would be possible, since all of it would be sucked up by this one good. But human action is the be all and end all of economics. Without the former, there can be no latter. Thus we can ignore this option as even a logical possibility.

Similarly with a zero price. Here, what was previously a good can no longer be considered as such. At a zero price, a good ceases to be a good. It now becomes «a general condition of human welfare. $\gg^{7}$ But if it is no longer a good, it need not anymore concern us. We are interested, solely, in scarce items, and this simply does not apply to things without a price.

An identical analysis applies to the quantity dimension, in which «misbehaving» $S$ and $D$ curves, once we move away from «equilibrium» and we must, since human action implies no less, result in either zero or infinite amounts. The problem with the former is that if there is nothing of a good at all produced, it is hardly an economic good, and therefore no longer concerns us. The difficulty with an infinite amount of a good is that, like a black hole, it sucks literally everything down into the vortex with it. As in the case of the infinite price, an infinite quantity is logically incompatible with finite human action, the sine qua non of economics.

\section{$\mathrm{V}$ \\ THE INVALIDITY OF SUPPLY AND DEMAND CURVES FROM AN AUSTRIAN PERSPECTIVE}

There is yet another ground upon which to object to the thesis that Giffen Goods and BBSCs obviate the praxeological status of

7 This is instead of «free good» to denote a desirable element of the environment that is in superabundance and therefore is not the object of action. We owe this point to Joe Salerno. See on this http://www.mises.org/humanaction/chap4sec1.asp; http://www.mises.org/rothbard/mes/chapla.asp 
the claim that price controls play havoc with the economy: supply and demand curves, strictly speaking, are incompatible with human action. In our view (Barnett and Block, unpublished) choice is essentially binary. We can either produce or consume, there is no third option. ${ }^{8}$ Further, if one consumes, one can only consume A or non A. All options other than A fall into the latter category. Even with regard to any one good, A, binaryism still applies: one can either purchase it, or fail to do so, at a given price.

How to reconcile this binary Austrian way at looking at economics with supply and/or demand curves? In a word, it cannot be done. Either of these collections of dots in price quantity space is as incompatible with the binary vision as is a fish riding a bicycle. These loci of points are (at least theoretically) composed of an indefinitely large number of price quantity combinations. As a heuristic device, as a pedagogical tool, they are unexceptionable; even, helpful. But, just as the dog must wag the tail, not the other way around, we must not allow ourselves to be controlled and mislead by theoretical constructs of our own devising. As Mises $(1949,45)$ says: «Human life is an unceasing sequence of single actions.»

According to the thesis we are contending against, when we cannot rule out the presence of a Giffen good or a BBSC, supply and demand curves do not slope in their usual directions. This being the case, the standard analysis of price controls, predicated upon the well behavedness of these curves, can only be believed contingently, not as a matter of praxeology. The point we are making in this section is that supply and demand functions are good heuristic devices, but theoretically problematic. If (misbehaving) supply and demand curves will not allow us to draw our standard theoretical conclusions about price controls on a synthetic apriori basis, then so much the worse for using such geometrical figures. Their pedagogical benefits are outweighed, at least in this case of misbehavior, by ontological considerations.

Nor are supply and demand curves needed in order to establish the effects of price minima or maxima. We know as a matter

8 Barnett and Block (forthcoming) demonstrates that money does not constitute a third alternative. 
of apodictic certainty, for example, that when a minimum wage is imposed, those with marginal revenue products (MRPs) below that stipulated level will tend not to be employed, at least in the long run. That if they are, despite this economic law, then firms which recklessly do so will court bankruptcy. If supply and demand analysis can illustrate this conclusion, well and good. If it cannot, ${ }^{9}$ then so much the worse for this sort of examination. It was not for nothing that not a single solitary set of supply and demand curves appeared in all of Mises (1998). This author could say just about everything worth saying in economics without utilizing these equations in geometric form. In some cases, they are no doubt useful tools. But if ${ }^{10}$ they clearly mislead us, for example, by appearing to indicate that price controls have no effect at all, or, worse, benevolent effects, or, seem to conflict with our knowing this on an apodictic basis, then it is time, it is long past time, that we jettison these tools of «analysis.»

\section{BIBLIOGRAPHICAL REFERENCES}

Anderson, William, Block, Walter, DiLorenzo, Thomas J. , Mercer, Ilana, SNYMAN, Leon and WestLey, Christopher (2001): «The Microsoft Corporation in Collision with Antitrust Law,» The Journal of Social, Political and Economic Studies, Vol. 26, ․o 1, Winter, pp. 287-302.

Armentano, Dominick T. (1972): The Myths of Antitrust, New Rochelle, N.Y.: Arlington House.

- (1982): Antitrust and Monopoly: Anatomy of a Policy Failure, New York, Wiley.

- (1991): Antitrust Policy: The Case for Repeal, Washington,

D.C.: The Cato Institute.

Armstrong, Donald (1982): Competition versus Monopoly: Combines

Policy in Perspective, Vancouver: The Fraser Institute.

BARNETT, William and BLOCK, Walter. Forthcoming. "Money:

Capital Good, Consumers' Good, or (Media of) Exchange

9 This is a concession we have not made; we have only done so arguendo.

${ }^{10}$ Note, we do not say «when.» 
Good? Money as a Producers' or Consumers' Good?» Review of Austrian Economics.

- Unpublished. «Human action is binary.»

BAtEMARCO, Robert (1985): «Positive Economics and Praxeology: The Clash of Prediction and Explanation,» Atlantic Economic Journal, July, 13(2), pp. 31-27.

BeCKER, Gary (1995): «It's Simple: Hike the Minimum Wage, and You Put People Out of Work,» Business Week Magazine, 6 March.

BLOCK, Walter and BARNETT, William. Unpublished. "An Austrian Critique of Neo-Classical Monopoly and Monopsony Theory».

BLOCK, Walter (1973): "A Comment on "The Extraordinary Claim of Praxeology" by Professor Gutierrez,» Theory and Decision, June, 3(4), pp. 377-387.

- (1977): «Austrian Monopoly Theory - a Critique,» The Journal of Libertarian Studies, Vol. I, N.․ 4, Fall, pp. 271-279.

- (1982): Amending the Combines Investigation Act, Vancouver: The Fraser Institute.

- (1986): "A Comment on "Towards an Economic Theory of Methodology" by Professor Gerard Radnitzky,» Methodology and Science, 19(2), pp. 148-152.

- (1994): «Total Repeal of Anti-trust Legislation: A Critique of Bork, Brozen and Posner, Review of Austrian Economics, Vol. 8, N.o 1, pp. 35-70; http:/ / www.mises.org/journals / rae/pdf/rae8_1_3.pdf

- (1999): «Austrian Theorizing, Recalling the Foundations: Reply to Caplan,» Quarterly Journal of Austrian Economics, Vol. 2, N.o 4, winter, pp. 21-39; http://www.mises.org/ journals/qjae/pdf/qjae2_4_2.pdf; errata: http://www. mises.org/journals/qjae/pdf/qjae2_4_9.pdf

- (2003): «Realism: Austrian vs Neoclassical Economics, Reply to Caplan,» Quarterly Journal of Austrian Economics, Vol. 6, N.. 3, Fall, pp. 63-77.

BÖHM-BAWERK, Eugen von: «The Historical vs. the Deductive Method in Political Economy,» Annals of the American Academy of Political and Social Science, vol. 1, 1890; and Classics in Austrian Economics, Volume 1: The Founding Era, Israel M. Kirzner, ed., London: William Pickering, 1994, pp. 108-129. 
Bostaph, Samuel (1978): «The Methodological Debate between Carl Menger and the German Historicists," Atlantic Economic Journal, 6(3), reprinted in Mark Blaug, ed., Carl Menger (1840-1921), Cambridge: Elgar, 1992.

Boudreaux, Donald J., and DiLorenzo, Thomas J. (1992): «The Protectionist Roots of Antitrust,» Review of Austrian Economics, Vol. 6, N. 2, pp. 81-96.

BuchanAN, James (1982): «The Domain of Subjective Economics: Between Predictive Science and Moral Philosophy,» in Method, Process, and Austrian Economics, Israel Kirzner, ed., Lexington, MA: Lexington Books.

CARD, David, and KRUEger, Alan B. (1994): «Minimum Wages and Employment: A Case Study of the Fast-Food Industry in New Jersey and Pennsylvania,» American Economic Review, Vol. 84, N. 4, September, pp. 772-793.

CowAn, Robin and Rizzo, Mario (1996): «The Genetic-Causal Tradition and Modern Economic Theory.» Kyklos, vol. 49, Fasc. 3, 1996, pp. 273-317.

Cubeddu, Raimondo (1993): The Philosophy of the Austrian School. New York: Routledge, pp. 1-108.

Deere, Donald, Murphy, Kevin M., and Welch, Finis (1995): «Sense and Nonsense on the Minimum Wage.» Regulation: The Cato Review of Business $\mathcal{E}$ Government. Vol. 18, N. 1. http:/ / www. cato.org/pubs/regulation/reg18n1c.html (accessed on 2/24/04).

DiLorenzo, Thomas J., (1997): «The Myth of Natural Monopoly,» Review of Austrian Economics, Vol. 9, ‥ 2, pp. 43-58.

DiLorenzo, Tom and High, Jack (1988): «Antitrust and Competition, Historically Considered,» Economic Inquiry, July.

Friedman, Milton (1953): Essays in positive economics, Chicago: University of Chicago Press.

GARRISON, Roger W. (1985): «Predictable Behavior: Comment. American Economic Review, vol. 75, n. ${ }^{\circ}$ 3, June, pp. 57678.

Gordon, David (1993a): «Ludwig von Mises and the Philosophy of History,» in The Meaning of Ludwig von Mises, Jeffrey M. Herbener ed., Auburn, AL: Ludwig von Mises Institute; Boston, MA: Kluwer, pp. 118-133. 
- (1993b): «The Philosophical Contributions of Ludwig von Mises,» Review of Austrian Economics, 7(1), pp. 95-106.

High, Jack (1984-1985): «Bork's Paradox: Static vs Dynamic Efficiency in Antitrust Analysis,» Contemporary Policy Issues, Vol. 3, pp. 21-34.

Hoppe, Hans-Hermann (1989): «In Defense of Extreme Rationalism: Thoughts on Donald McClosky's The Rhetoric of Economics,» Review of Austrian Economics, 3, pp. 179-214.

- (1990): "Austrian Rationalism in the Age of the Decline of Positivism,» in Austrian Economics: Perspectives on the Past and Prospects for the Future, Vol. 17, Richard M. Ebeling, ed., Hillsdale, MI: Hillsdale College Press, pp. 59-96.

- (1995): Economic Science and the Austrian Method. Auburn, AL: Ludwig von Mises Institute

HulsmanN, Jorg Guido (2000): «A Realist Approach to Equilibrium Analysis.» Quarterly Journal of Austrian Economics. Vol. 3, N.. 4 , Winter, pp. 3-51.

Huerta DE Soto, Jesus (1998): «The Ongoing Methodenstreit of the Austrian School,» Journal des Economistes et des Etudes Humaines, March, (8: 1), 75-113.

KiRZNER, Israel M. (1976a): «On the Austrian Method in Economics, , The Foundations of Modern Austrian Economics, Edwin G. Dolan, ed. Kansas City: Sheed and Ward, pp. 40-51.

- (1976b): The Economic Point of View, Kansas City: Sheed and Ward, 1976.

Mankiw, N. Gregory (2001): The Cost of a «Living Wage: We can't ignore law of supply and demand.» The Boston Globe. June 24. http: / / post.economics.harvard.edu/faculty / mankiw/columns/bglobejune01.html

MCChesney, Fred (1991): "Antitrust and Regulation: Chicago's Contradictory Views,» Cato Journal, Vol. 10.

Menger, Carl (1960): «Toward a Systematic Classification of the Economic Sciences, » in Essay in European Economic Thought, Louise Sommer, ed. Princeton, NJ: Van Nostrand, pp. 1-38. Mises, Ludwig von (1976): Epistemological Problems in Economics, New York: New York University Press

- (1978): The Ultimate Foundation of Economic Science, Kansas City: Sheed Andrews and McMeel. 
- (1985): Theory and History: An Interpretation of Social and Economic Evolution, Auburn, AL: Ludwig von Mises Institute.

- (1990): «The Treatment of "Irrationality" in the Social Sciences,» Money, Method, and the Market Process, Richard M. Ebeling, ed., Boston, MA: Kluwer Academic Publishers, pp. 16-36.

- (1998): Human Action, Chicago: Regnery.

Neumark, David and WAScher, William (1995): The Effect of New Jersey's Minimum Wage Increase on Fast-food Employment: A Re-evaluation using Payroll Records. NBER Working Paper: Cambridge, MA.

Rizzo, Mario (1979): «Praxeology and Econometrics: A Critique of Positivist Economics,» in New Directions in Austrian Economics, Louis Spadaro, ed. Kansas City: Sheed Andrews and McMeel, pp. 40-56.

RothbARD, Murray N. (1970): Man, Economy, and State, Los Angeles, Nash, ch. 10.

- (1951): «Praxeology: Reply to Mr. Schuller.» American Economic Review, December.

- (1957): «In Defense of Extreme Apriorism,» Southern Economic Journal, January, 23(1), pp. 314-320.

- (1976.): «Praxeology: The Methodology of Austrian Economics,» in The Foundations of Modern Austrian Economics. Edwin G. Dolan, ed., Kansas City: Sheed and Ward, pp. 1939.

- (1993 [1970]): Man, Economy, and State, Auburn, AL: Ludwig von Mises Institute.

- (1997): The Logic of Action One. Murray N. Rothbard, ed., UK: Edward Elgar Publishing Limited

Selgin, George A. (1988): «Praxeology and Understanding: An Analysis of the Controversy in Austrian Economics,» Review of Austrian Economics, (2), pp. 19-58.

Shugart II, William F. (1987): «Don't Revise the Clayton Act, Scrap It!,» 6 Cato Journal, 925.

SмITH, Barry (1996): «In Defense of Extreme (Fallibilistic) Apriorism,» Journal of Libertarian Studies, 12, pp. 179-192.

SMITH, Jr., Fred L. (1983): «Why not Abolish Antitrust?». 
DIAGRAM 1

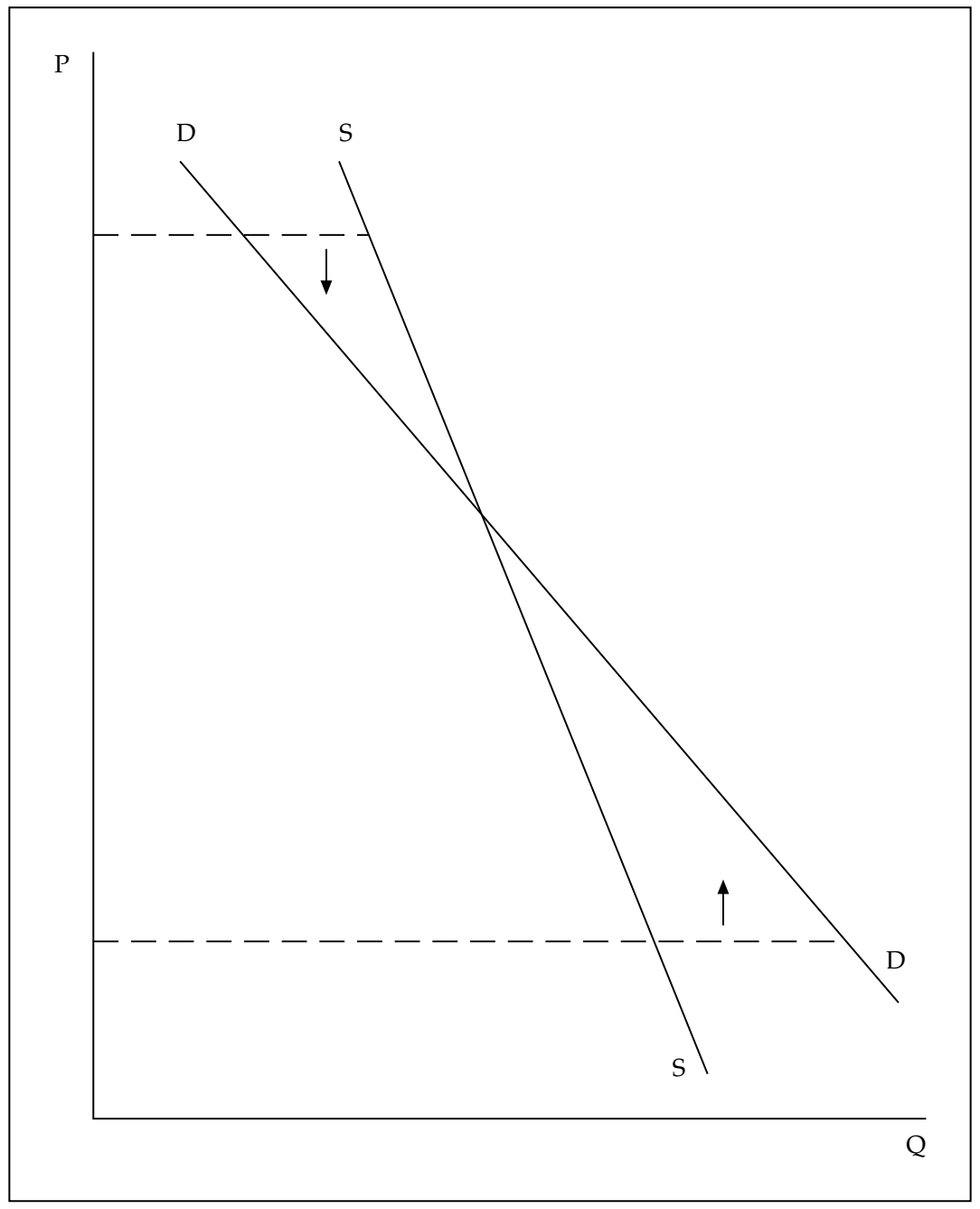




\section{DiAgRAM 2}

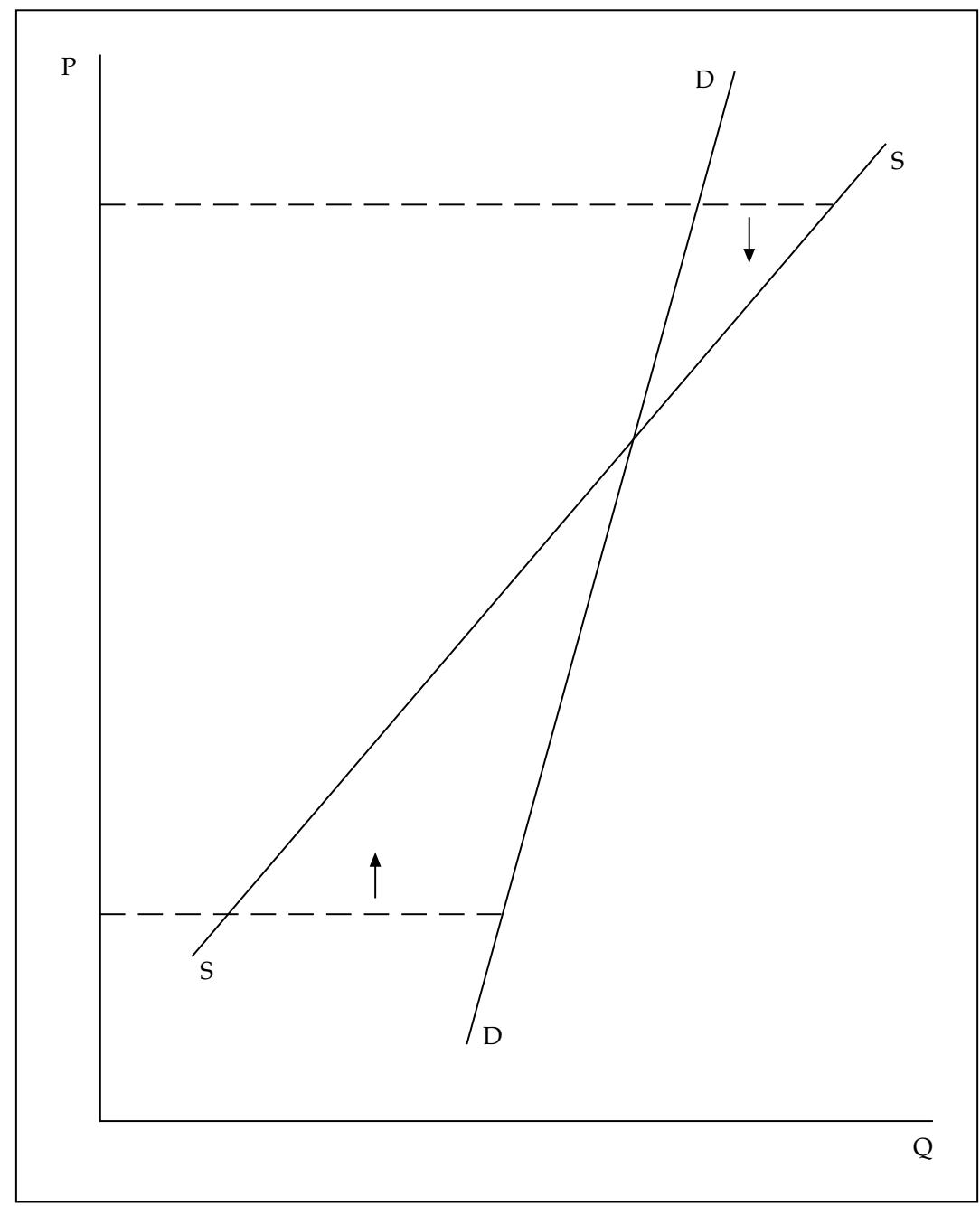




\section{DiAgRAM 3}

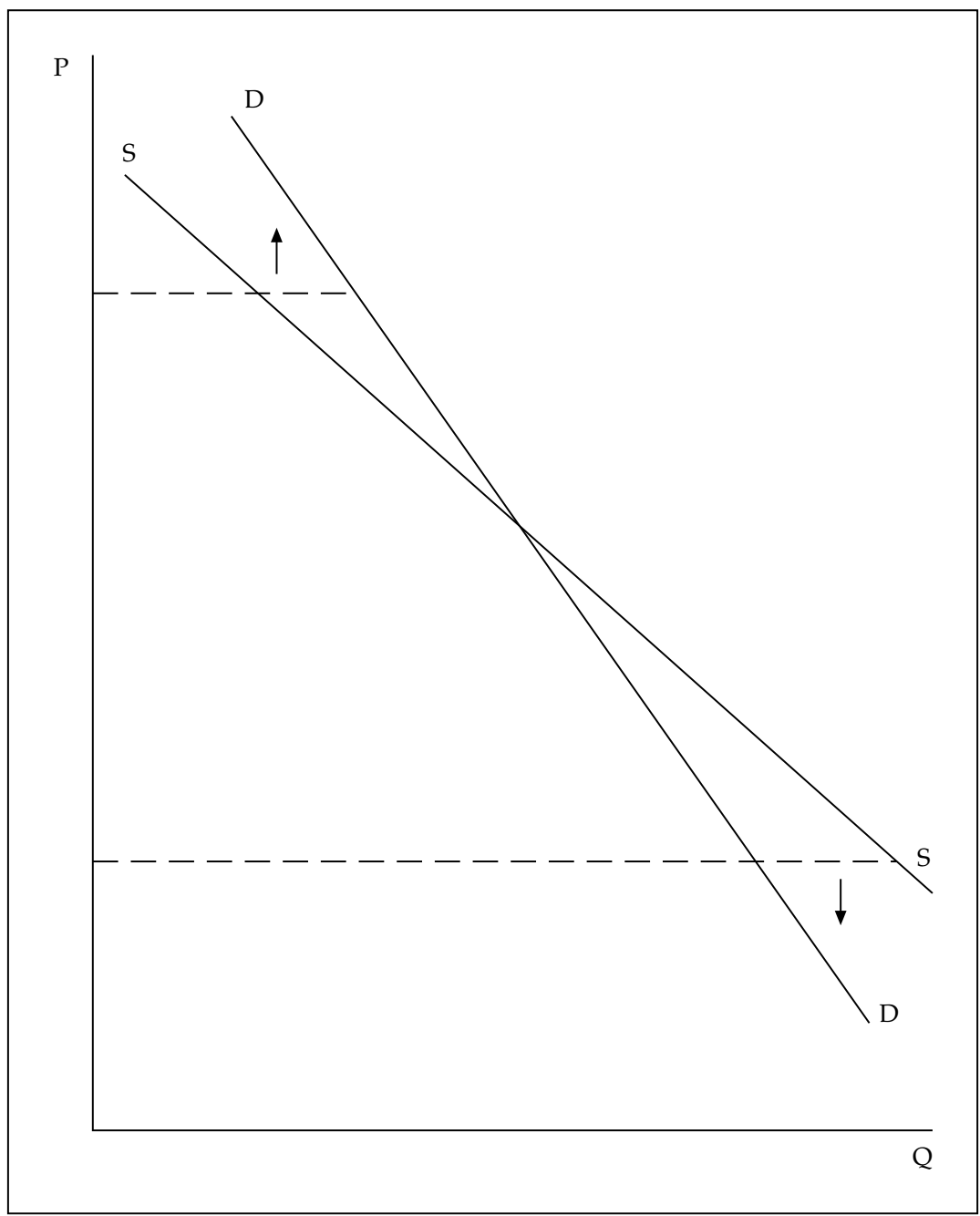


DIAGRAM 4

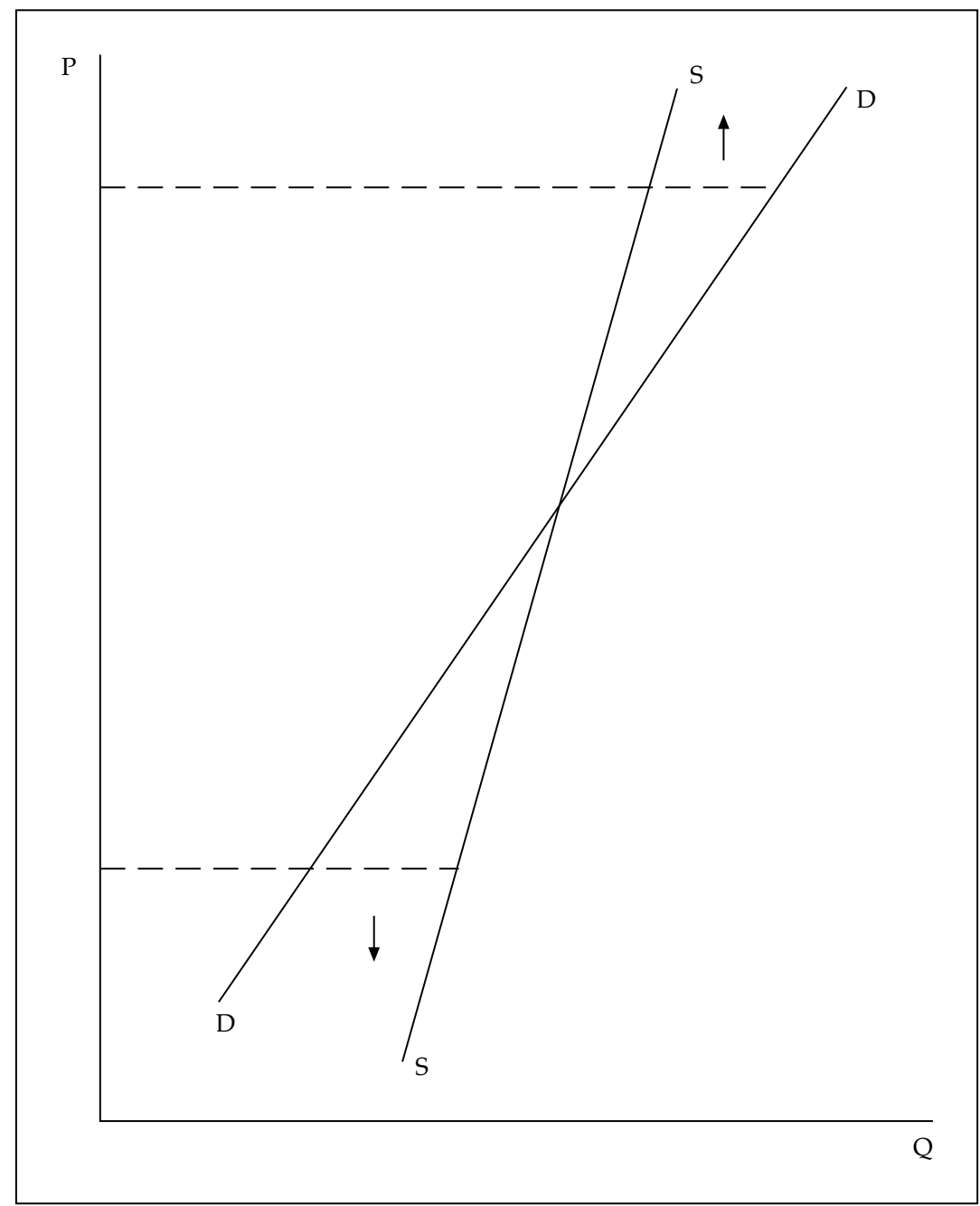




\section{DiAgram 5}

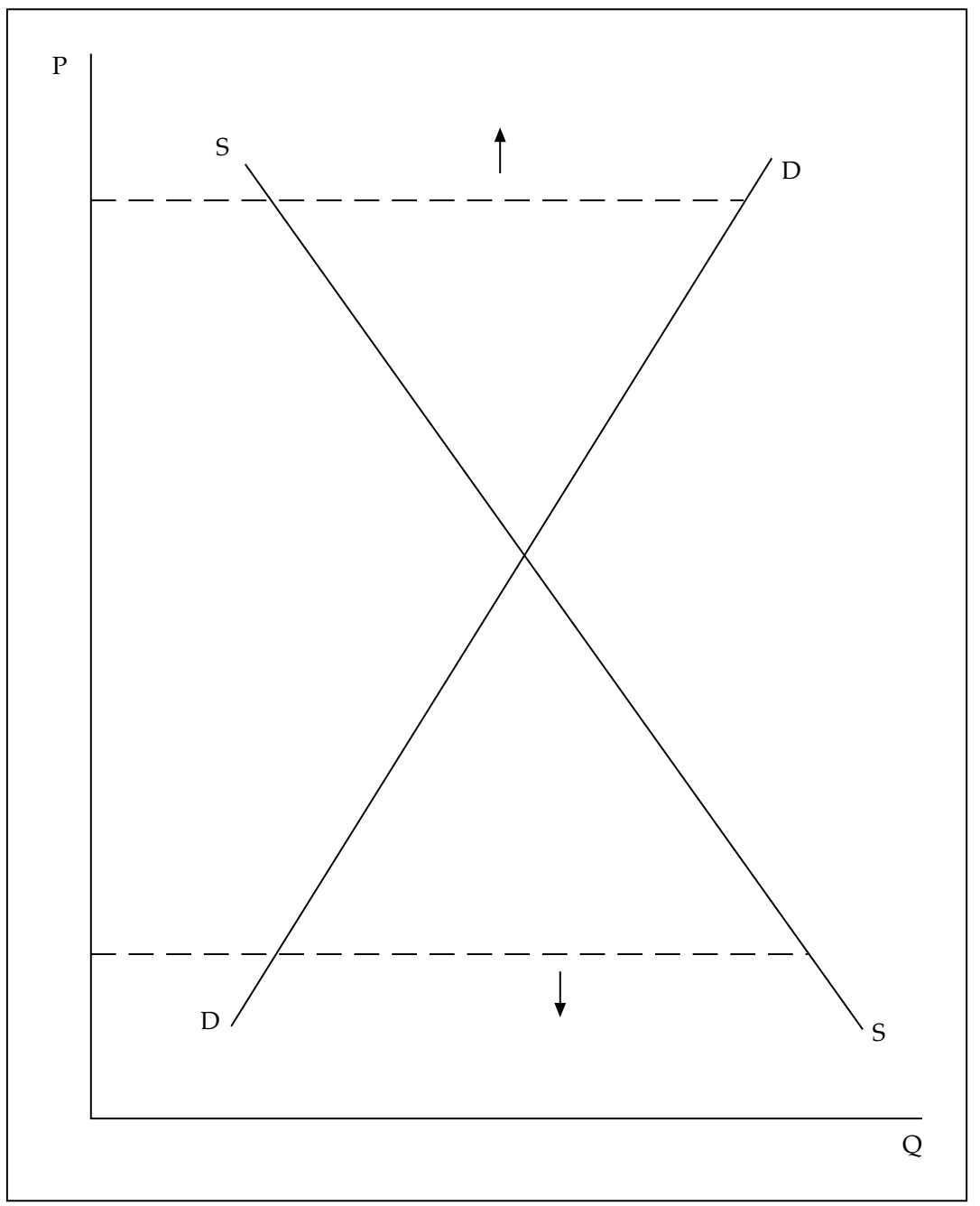




\section{DiAgRAM 6}

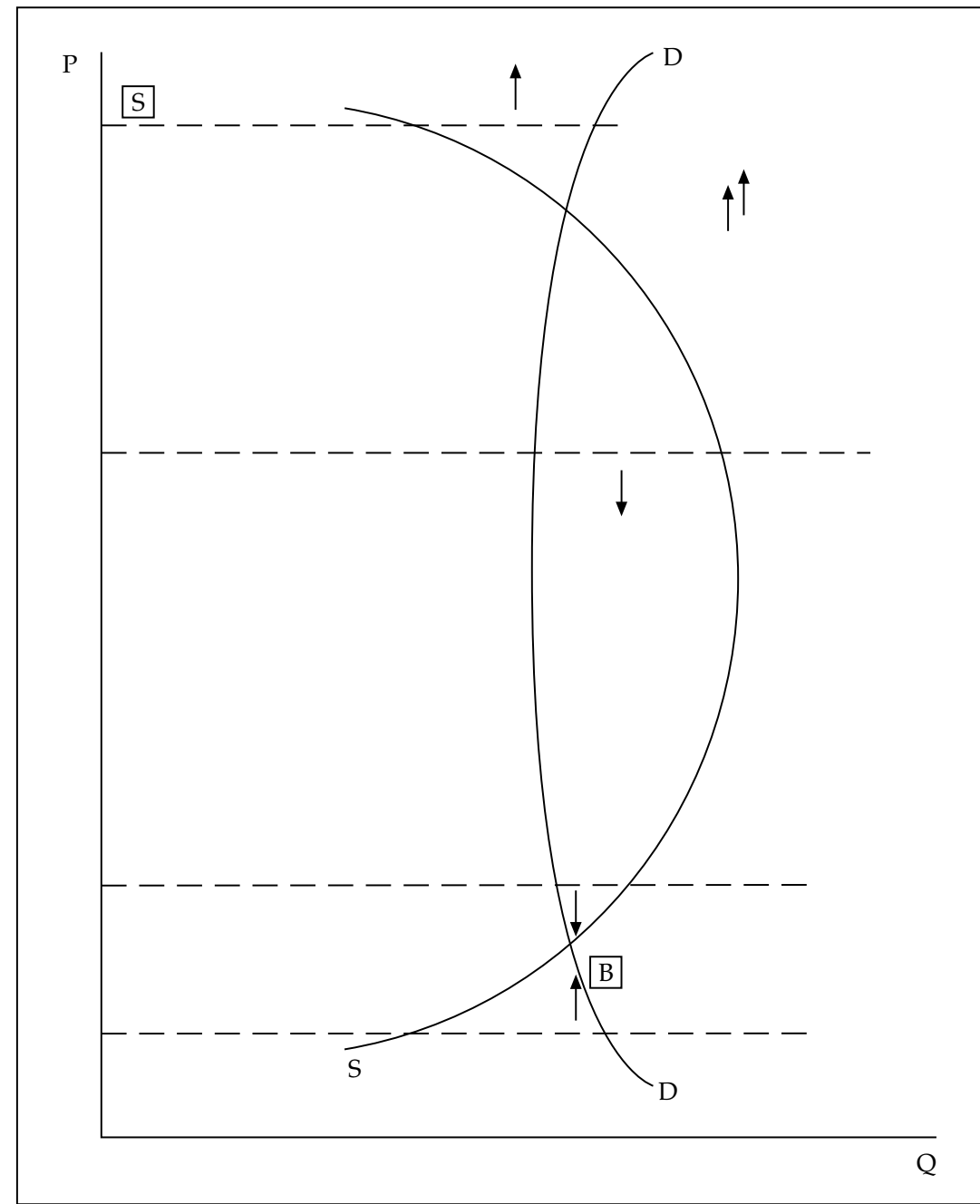


DIAGRAM 7

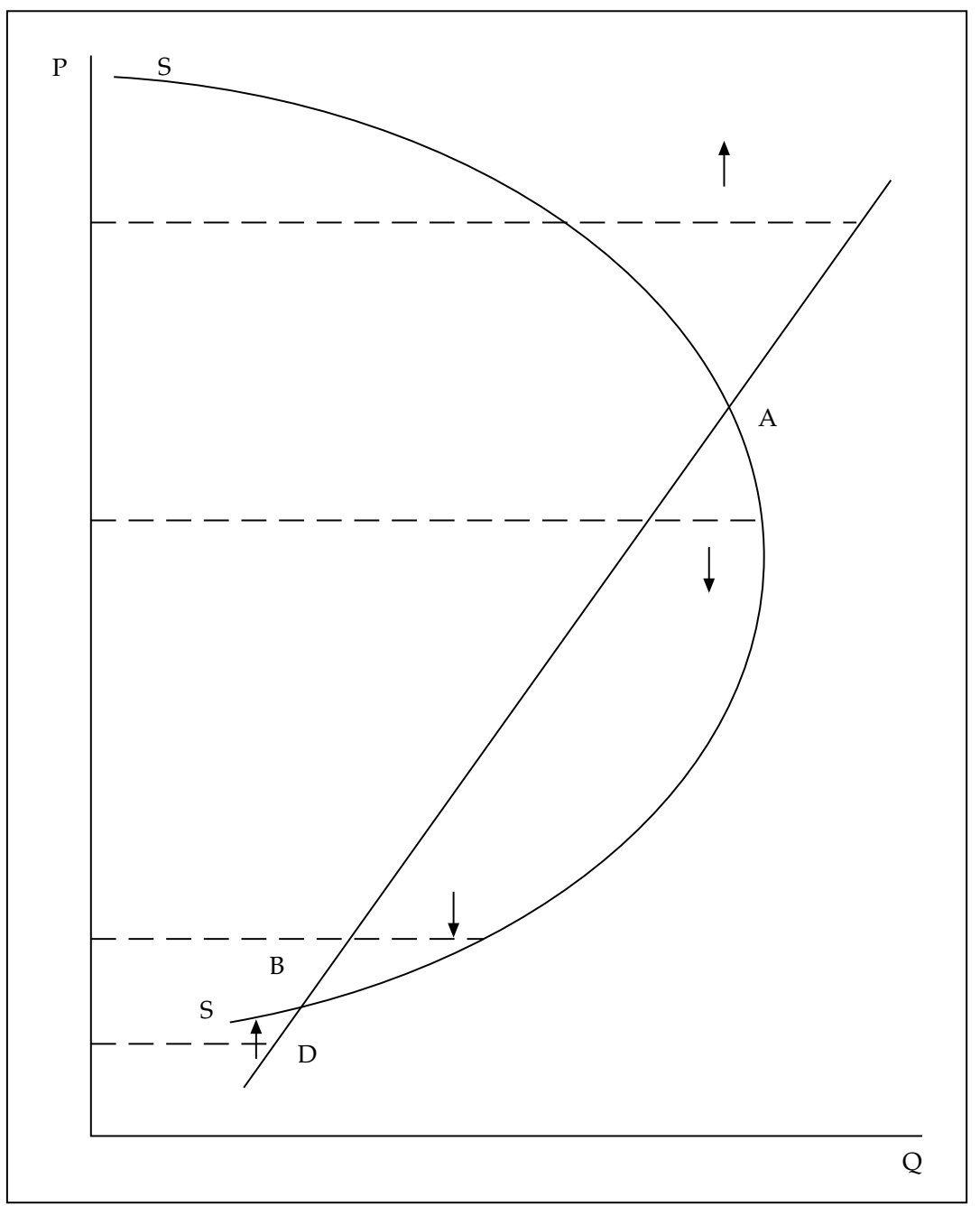

